\title{
PAISAGENS, GEOSSÍMBOLOS E DIMENSÕES DA CULTURA EM COMUNIDADES QUILOMBOLAS
}

\author{
sceneries, geosymbols and dimensions of the culture in Maroon Communities from Paraíba
}

\author{
Maria de Fátima Ferreira Rodrigues*
}

\begin{abstract}
Resumo
Este trabalho tem como objetivo interpretar as estratégias de resistência de comunidades quilombolas da Paraíba, com destaque para alguns aspectos da memória social que coloca em cena a alteridade, e também conquistas decorrentes de processos organizativos fundados num ideal democrático, cujos argumentos políticos estão respaldados em pressupostos históricos e em Tratados Internacionais ratificados pelo Estado brasileiro. Adotamos como referência para a pesquisa, duas escalas de análise: a escala estadual, com a qual trabalhamos a pesquisa documental e dados quantitativos, aportados em órgãos e portais especializados, e a escala local com a qual trabalhamos as comunidades de Caiana dos Crioulos, Pitombeira e Paratibe. Utilizamos como principais referências teóricas ANJOS (2006), RATTS (2003) e ARRUTI (2003), para abordarmos o território e a questão étnica; ALMEIDA (2004), HAESBAERT (2004a, 2008b) e ANDRADE (1995), para discutirmos o território do ponto de vista institucional e simbólico; ancoramos-nos em HALBWACHS (1990), BOSI (1992) e LE GOFF (1994) para registrar aspectos significativos da memória coletiva, dada a sua importância no processo identitário e, para nos fundamentarmos sobre os procedimentos adequados a uma abordagem oral na pesquisa, buscamos apoio em QUEIROZ (1988) e AMADO, J.; FERREIRA, M.M. (2001).
\end{abstract}

Palavras-chave: Quilombolas, território, Geografia cultural.

\begin{abstract}
This work aims to interpret the resistance strategies of maroon communities in Paraíba, highlighting some aspects of the social memory which evidences the otherness, but also achievements resulting from organizational processes grounded in the ideals of democracy, whose political support is based in historical assumptions and in International Treaties countersigned by Brazilian State. We choose as a reference to the survey two scales of analysis: the state scale, in which we work with document research and quantitative data based on information from official organs and specialized portals, and, the local scale in which we work with the maroon communities of Caiana dos Crioulos, Pitombeira, and Paratibe. We used as the main theoretical references, ANJOS (2001), RATTS (2003) and ARRUTI (2003), to approach the territory and the ethnic issue; ALMEIDA (2004), HAESBAERT (2004a) and ANDRADE (1995) to discuss the territory from the institutional and symbolic point of view; HALBWACHS (1990), BOSI (1992) and LE GOFF (1994 ) to register significant aspects of collective memory, given its importance in the identity process and, to fundament ourselves for the appropriate procedures to a oral approach in the research we sought support in QUEIROZ (1988) and AMADO, J.; FERREIRA, M.M. (2001).
\end{abstract}

Key words: Marrons, territory, Cultural Geography.

\begin{abstract}
Résumé
Ce travail a pour objectif l'interprétation des stratégies de résistance de communautés quilombolas de la Paraíba, avec une attention toute particulière concernant certains aspects de la mémoire sociale que met en scène l'altérité, mais aussi les acquis provenant des processus d'organisation fondés sur un idéal démocratique, dont les arguments politiques s'appuient sur des Traités Internationaux ratifiés par l'État brésilien. Nous adoptons comme référentiel de recherche deux échelles d'analyse: l'échelle de l'État à partir de laquelle nous travaillons la recherche documentaire et les données quantitatives, présentes au sein des organismes et des portails spécialisés, et l'échelle locale à partir de laquelle nous travaillons les communautés de Caiana dos Crioulos, Pitombeira et Paratibe. Nous utilisons comme principales références théoriques ANJOS (2001), RATTS (2003) et ARRUTI (1997), pour aborder le territoire et la question éthnique; ALMEIDA (2004), HAESBAERT (2004a, 2008b) et ANDRADE (1995), pour discuter le territoire du point de vue institutionnel et symbolique; nous nous appuyons sur HALBWACHS (1990), BOSI (1992) et LE GOFF (1994 ) pour souligner des aspects significatifs de la mémoire collective, étant donné son importance dans le processus identitaire et, pour nous fonder sur les procédés adéquats à un abordage oral lors de la recherche, nous nous réfèrons à QUEIROZ (1988) et AMADO, J.; FERREIRA, M.M. (2001).
\end{abstract}

Mots clé: Quilombolas, territoire, Géographie culturelle.

(*) Pof ${ }^{\mathrm{a}}$. Dr ${ }^{\mathrm{a}}$. da Pós-Graduação em Geografia da Universidade Federal da Paraíba - Campus I, Cidade Universitária, CEP: 58.059-900 - Joao Pessoa (PB) - Brasil, Tél/Fax..: (+ 55 83) 3216.7432 / 3216.7595 - fatimarodrigues.ufpb@gmail.com 


\section{INTRODUÇÃO}

Este trabalho tem como objetivo interpretar as formas de resistência dos negros e negras da Paraíba, destacando os aspectos formais e jurídicos que dizem respeito ao processo de identificação e demarcação das terras, conforme exige a legislação em vigor, mas busca destacar, sobretudo, as formas de resistência e as conquistas sociais decorrentes de processos organizativos fundados num ideal democrático que tem sustentação política em pressupostos históricos e em Tratados Internacionais referendados pelo Estado brasileiro. Embora trabalhemos com o território estadual, priorizamos a análise de dados qualitativos e quantitativos referentes às comunidades quilombolas de Paratibe, localizada no município de João Pessoa, Mesorregião da Mata Paraibana; Caiana dos Crioulos, situada no município de Alagoa Grande, Mesorregião do Agreste; e, Pitombeira, situada no município de Várzea, Mesorregião da Borborema. As três comunidades mencionadas, situadas em diferentes regiões do estado, comportam histórias que ora se assemelham, ora se diferenciam em decorrência das especificidades sócio-espaciais que as caracterizam.

Em nossa reflexão buscamos elucidar o processo de construção da territorialidade étnica dessas comunidades, interpretando as formas de organização política, as redes de solidariedade, bem como processos de trabalho, identificando as suas práticas culturais, base do modo de vida camponês. Analisamos as suas tradições, considerando-as num movimento que se estende pela ordem econômica para concretizar-se numa ordem moral, que traduz a sua campesinidade, com base em Woortmann, (1990, p. 43) que considera o espaço camponês como um espaço moral, de reciprocidade e de trabalho, portanto "[...] o trabalho é o significado da família, como o é, igualmente, a terra enquanto patrimônio. Mais que o objeto de trabalho, a terra é o espaço da família."É com esta valoração que a terra é entendida e defendida pelas comunidades quilombolas em tela, a despeito das pressões exercidas pela sociedade envolvente. Esse entendimento de que nos acercamos, nos possibilita dialogar com Castro, (2001, p.264) que assim como o faz MOURA (1986) e, MARTINS (1981) assegura: "A luta pela terra que o campesinato tem deflagrado é uma luta pela sua recriação. Recriação, porque se dá mediante processos não-lineares dentro de sua reconstituição histórica, ou seja, atravessa descontinuidades."

A recriação da terra camponesa é um tema que ocupa Martins (1986, p. 177 ) desde a década de 1980 e para esse autor o campesinato "Cria riqueza que se realiza em mãos estranhas às suas, como renda que flui disfarçadamente para os lucros bancários, como alimento de custo reduzido que barateia a reprodução da força de trabalho industrial e incrementa a taxa de lucro das grandes empresas urbanas."

A essa interpretação sobre a expropriação dos camponeses da terra e sobre a apropriação da renda camponesa pelas elites, conflitos e disputas por terra, o mesmo autor acrescenta um dado relevante a interpretação do tema ao assegurar que: "Enquanto o lavrador luta pela terra de trabalho, a grande empresa capitalista luta pela renda da terra." (MARTINS, 1986, p. 77).

A renda fundiária está no cerne dos embates pela posse da terra e mobiliza o patronato rural (LEAL, 2003; BRUNO, 2003) em entidades como a Confederação Nacional de Agricultores - CNA e a União Democrática Ruralista - UDR, dentre outras entidades, e encontra oposição no campesinato organizado em diversos movimentos sociais que ocupam o cenário da luta pela terra no campo brasileiro: com destaque para o Movimento dos Trabalhadores Rurais Sem- Terra (MST), o Movimento dos Atingidos Por Barragens - MAB, o Movimento dos Pequenos Agricultores (MPA), dentre outros. A disputa por território a partir da questão étnico-racial encontra respaldo no Movimento Negro Unificado que, segundo Moreira (2006), representa mais de quarenta entidades e grupos de negros organizados na Paraíba, também encontra apoio em associações comunitárias locais, através das quais costumam encaminhar os seus pleitos às autoridades e gestores. Cabe dizer que as disputas pelos territórios étnicos na Paraíba mobilizam além dos negros, índios e ciganos. 
$\mathrm{Na}$ análise do território aportamos autores como RAFFESTIN (1993), ANDRADE (1995) SANTOS (2006), e HAESBAERT (2004), cujas reflexões permitem pensá-lo do ponto de vista simbólico e material: dimensões que em nosso entender, embora possam parecer apartadas para os de fora, para os de dentro, os que constroem o território, ora se apartam ora se fundem num movimento que os aproxima e sincroniza mobilidades populacionais e dinâmicas territoriais. Nesse sentido, a existência do território costuma ser associada as atividades decorrentes do processo de ocupação e, por conseguinte da economia, transporte, fiscalização, comércio, produção etc. Essa compreensão do território se revela em Andrade (1995, p.20) para quem "A formação de um território dá as pessoas que nele habitam a consciência de sua participação, provocando o sentido da territorialização que, de forma subjetiva, cria uma consciência de confraternização entre elas." (ANDRADE 1995, p.20).

Chamamos a atenção para o que destaca Haesbaert, (2007, p. 43), quando este autor apoiado em reflexões de Di Meo, afirma que desde a origem, o território nasce com uma conotação fortemente vinculada a terra e ao território, pois "etimologicamente a palavra território, territorium em latim, é derivada diretamente do vocábulo latino terra."

Ao destacar os sentidos que têm as palavras terra e território lembramos sobre o que nos adverte Bosi, (1992, p.11), em relação à importância da linguagem no processo de investigação, ao afirmar: "começar pelas palavras talvez não seja coisa vã. As relações entre os fenômenos deixam marcas no corpo da linguagem".

Atenta aos sentidos de conceitos como o de camponês, e latifundiário, colônia e colonizador, cultura e agricultura (MARTINS, 1992), interessa registrar no debate sobre terra e o território não só as possibilidades de interpretações a partir da dimensão material, mas também das dimensões simbólicas que o tema pode comportar. Com isso ancoramo-nos em perspectivas interdisciplinares e em debates que tiveram suas origens na crise dos paradigmas e têm suporte em autores que atravessam uma linha de tempo que se estende desde as primeiras décadas do sec. XX, a exemplo de BACHELARD (1996), quando discute os obstáculos epistemológicos, até debates que têm início no Brasil no começo da década de 1990, levados adiante por autores como Morin, (1986. p.14) que afirma estar a verdade ligada a uma busca sobre a possibilidade da verdade e argumenta que "a noção de conhecimento que nos parece una e evidente, quando a interrogamos, ela arrebenta, multiplica-se em inúmeras noções, cada uma das quais põe uma nova interrogação”. Do mesmo modo nos acercamos de interpretações que marcam o pensamento de SANTOS (2007) que propõe uma sociologia insurgente baseada em cinco ecologias: ecologia dos saberes, das temporalidades, do reconhecimento, da transescala e das produtividades para propor a adoção de uma ecologia dos saberes e a superação da monocultura dos saberes. Na base do roteiro proposto por esse autor está a busca de "credibilizar, ampliar simbolicamente as possibilidades de ver o futuro a partir daqui." (SANTOS, 2007, p. 37-38). Foi seguindo esse percurso que interpretamos as questões étnico-raciais nas comunidades quilombolas da Paraíba, sem perder de vista os pressupostos políticos que embasam as demandas por terra e território, em suas especificidades.

Do ponto de vista dos procedimentos metodológicos, realizamos um levantamento bibliográfico sobre a temática, na Biblioteca Central e nas bibliotecas setoriais da Universidade Federal da Paraíba (UFPB); pesquisa documental no Instituto Nacional de Colonização e Reforma Agrária (INCRA) e nas Associações de Moradores das Comunidades Quilombolas de Caiana dos Crioulos e Paratibe, por ocasião dos trabalhos de campo. Pesquisamos também em portais como o do Instituto Brasileiro de Geografia e Estatística (IBGE), da Fundação Nacional de Saúde (FUNASA), Fundação Palmares, Secretaria de Políticas de Promoção da Igualdade Racial - SEPPIR.

As monografias, dissertações e teses que abordam questões étnico-raciais na Paraíba, foram de grande relevância para a fundamentação deste trabalho, pois, a partir dessas fontes, foi possível visualizar aspectos importantes da memória e pontuar um leque de questões exigidas pelo Estado brasileiro, do ponto de vista formal, para demarcação dos territórios quilombolas. 
Considerando a importância do conceito de memória coletiva no processo identitário, e para uma melhor compreensão do tema ancoramo-nos em HALBWACHS (1990), BOSI (1979 ), e LE GOFF (1994), embora tenhamos recorrido também a outros autores a exemplo de AMADO, J.; FERREIRA, M.M. (2001), QUEIROZ (1988), para nos fundamentarmos sobre os procedimentos adequados a uma abordagem oral na pesquisa.

A matriz teórica adotada para a interpretação da memória tem origem em HALBWACHS (1990) que a formula apoiado em Durkheim e, "não se refere à memória em si, mas aos quadros sociais em que ela é produzida. A memória não é, para ele, fruto do sonho, mas do trabalho de refazer, com idéias atuais, as experiências do pretérito". (OLIVEIRA, 2008, p. 55). (grifos meus).

A memória dos idosos embalou muitas das nossas conversas em campo e foi registrada em diversos momentos da pesquisa: por ocasião de eventos culturais em que as cirandas e cocos de roda animaram nossas chegadas e partidas, nas narrativas sobre a vida no lugar, nas explicações sobre as marcas na paisagem, os geossímbolos que marcam os caminhos, pontos de vivências, nas canções de trabalho entoadas nas diversas tarefas cotidianas, dentre outras manifestações da cultura.

Por fim, analisamos os dados levantados sobre a territorialização das comunidades quilombolas na Paraíba, conforme estão aportados nos órgãos oficiais, destacando avanços, rupturas e atrasos que impedem a apropriação dos territórios reivindicados.

\section{HISTÓRIAS QUE TRADUZEM A ANCESTRALIDADE CAMPONESA E JUSTIFICAM O DIREITO À TERRA QUILOMBOLA}

As narrativas sobre a terra das comunidades quilombolas de Caiana dos Crioulos, Pitombeira e Paratibe são impregnadas de histórias construídas no território, situações de mobilidade ocorridas no entorno onde vivem historicamente ou de mobilidades forçadas para terras distantes, movimentos também permeados por retornos constantes do lugar onde residem à terra de origem. Relatam vivências, experiências e conflitos rememorados pelos ancestrais, que remetem à própria história territorial dos municípios em que estão inseridos. Expõem, via de regra, situações de migrações em busca de condições de trabalho, ou até mesmo a procura de lugares isolados, distantes, onde até as suas necessidades imediatas ficaram ignoradas.

Em Caiana dos Crioulos, encontramos negros (as) que estavam retornando do Rio de Janeiro para visitar seus parentes, e esses nos informaram que estão inseridos em ciclos migratórios datados da década de 1940, mas encontramos, sobretudo, pais e mães de família que relatam as constantes migrações de seus filhos (as), nos últimos anos. A migração de Caiana para essa metrópole é tão intensa que eles costumam dizer: "há uma Caiana no Rio de Janeiro." Embora não tenhamos dados quantitativos que nos permitam objetivar essa informação, observa-se que, em cada família nuclear dessa comunidade, há no mínimo um de seus membros que mora no Rio de Janeiro, ou em outro centro metropolitano, em capitais da própria região Nordeste e com mais frequencia costuma ter passado por ciclos migratórios nas cidades situadas no próprio estado da Paraíba. Os relatos também evidenciam idas e vindas para João Pessoa e cidades adjacentes em busca de trabalho ou, até mesmo migrações para regiões mais distantes como a Amazônia. Sem terra de trabalho, os que ficam veem-se obrigados a trabalhar em parceria, pagando aos "donos da terra" a terça parte da produção que obtêm; outra forma de pagamento da renda dá-se, na apropriação do trabalho ao fazerem a limpeza da terra para o plantio, ou ao deixarem ao final da colheita as sobras de seus cultivos que servirão de alimento aos rebanhos dos proprietários de terra. As migrações se dão geralmente muito cedo quando, ainda jovens, buscam em todas as circunstâncias as condições dignas de sobrevivência. Os retornos são constantes tanto para sua terra de origem, quanto desta para os destinos preferidos como o Rio de Janeiro ou para outras localidades onde residem ou residiram. Os jovens retornam com frequência para visitar os parentes que ficaram e para concretizar enlaces matrimoniais com 
as jovens do lugar. Os retornos à comunidade contribuem para fortalecer os laços de parentesco, e também a própria identidade do grupo étnico, em suas dinâmicas territoriais, aprimorando também a troca de conhecimentos, e ratificando os laços de solidariedade.

Em Paratibe a migração é pendular, ocorre diariamente. Os habitantes dessa comunidade se deslocam, como a maioria dos trabalhadores urbanos, para seus locais de trabalho, visto que a ocupação de suas terras por loteamentos lhes restringiu a possibilidade de viverem da agricultura. Migram também para outros centros urbanos distantes da Paraíba e fazem com frequência os movimentos de retorno à comunidade.

Já em Pitombeira, o tema migração tem duas faces e fases que envolvem a história da comunidade em sua origem e, em sua relação com outras comunidades. Na fase mais recente, as migrações dos habitantes de Pitombeira acontecem tanto para cidades circunvizinhas quanto para os grandes centros urbanos. Mas, conforme anuncia o Sr. Ladislau, um dos nossos entrevistados, desde sua mocidade já havia migração da Pitombeira para outras localidades. Ele afirmou que essa migração se dava até mesmo para outros Estados.

Sobre a primeira fase dessa migração, os relatos memorialistas apontam que no sec. XIX um casal seguiu em direção ao Talhado, comunidade quilombola situada em Santa Luzia. Para esse deslocamento há duas explicações nas fontes consultadas: no filme Aruanda, de Linduarte Noronha, conforme destaca Nóbrega, (2007, p. 78) “Olho D’Água da Serra do Talhado em Santa Luzia do Sabugy, Estado da Paraíba, Nordeste do Brasil, surgiu em meados do século passado, quando o ex-escravo e madeireiro Zé Bento partiu com a família à procura da terra de ninguém. Com o tempo, o Talhado transformou-se num quilombo pacífico e isolado das instituições do país, perdido nas lombadas do chapadão nordestino [....]."

Ainda na versão de Nóbrega, (2007, p. 48) “o lugar disponibilizava, na época, recursos naturais compatíveis com os anseios do casal: madeira, caça do mato, mel e barro.” A justificativa para a migração do casal encontra respaldo, segundo esse autor, nas características físicas que ofereciam a localidade do Talhado visto que a esposa do Sr. Zé Bento, Dona Cecília Maria da Purificação, era uma artesã e nessa localidade existia a argila em abundância, matéria-prima adequada ao fabrico das peças que ela pretendia produzir; do mesmo modo existia a madeira, o que ensejava a possibilidade do ofício de carpinteiro exercido pelo Sr. Zé Bento.

Uma personagem e descendente desse casal, que ganhou status de representante dessa memória é a professora Givaneide. Ela costuma receber visitantes e pesquisadores na comunidade do Talhado e lhes contar a história do seu tronco familiar, conforme se verifica na dissertação de mestrado de NÓBREGA (2007), bem como em matéria jornalística recente noticiada no jornal A União, da qual reproduzimos o seguinte trecho:

A União: E como foi que tudo começou no Talhado?

Givaneide: Até 1860 o local era desabitado. Consta que o carpinteiro José Bento Carneiro - possivelmente um escravo alforriado - e sua mulher a louceira e parteira prática Cecília Maria da Purificação, foram os primeiros habitantes desta área, onde havia caça, água, mel, madeira e alimentos vegetais em abundância, além de terras boas para a agricultura.

Gilvaneide conta que se apegou à versão do escravo alforriado, porque Zé Bento comprou as terras em redor do Talhado com dinheiro vivo. Não invadiu nem criou refúgio, pois era carpinteiro conhecido e sua mulher vendia, pela vizinhança, as louças de barro que fabricava. A bisavó de Gilvaneide, Maria do Espírito Santo, era bisneta de Zé Bento (JORNAL A UNIÃO, 2010).

Essa memória da comunidade do Talhado, registrada em diferentes fontes, é também recorrente nos relatos orais que anotamos em nossos cadernos de campo e está presente em artigos publicados em anais de eventos e, de um modo geral, no acervo documental que temos no Gestar.

A despeito de ser Pitombeira o tronco inicial, a comunidade de Serra do Talhado obteve a Certidão de Registro no Cadastro Geral de Remanescentes de Comunidades de Quilombos, concedida 
pela Fundação Cultural Palmares (FCP) no ano de 2004, portanto antes de Pitombeira. Essa ligação histórica e de parentesco de Pitombeira com a comunidade do Talhado contribuiu para que iniciassem o processo de discussão sobre a necessidade de demarcação de suas terras e em 08/06/2005 foi também reconhecida como comunidade quilombola.

\section{CASAMENTO EM CAIANA: alteridade e identidade}

Em se tratando de eventos que traduzem traços identitários não poderíamos deixar de nos reportarmos ao cerimonial de casamento, evento permeado por lembranças vivenciadas pelos ancestrais em tempos passados e que por sua própria organização e caracterização se revela como um sinal diacrítico; um distintivo que propaga o grupo em relação a outros. Os rituais do casamento e até mesmo os preparativos para as festividades bem como as festividades em si, como ocorrem em Caiana, eram comuns no meio rural do Nordeste brasileiro. O grupo manteve a sua tradição distinguindo-se dos demais na realização desse ritual, conforme nos relata Moreira, (2009, p. 88/93), em dissertação de mestrado escrita sobre esta comunidade.

A cerimônia de casamento em Caiana dos Crioulos é um evento que mobiliza os membros da comunidade desde os preparativos, até a tão esperada festa. O dia 25 de janeiro de 2008 foi véspera de um desses eventos, onde os pais da noiva, os convidados e os noivos ajudaram nos últimos preparativos.

Vale salientar, que em outras áreas do Brejo paraibano, como no município de Pilões, os relatos dos casamentos de pessoas idosas são bem parecidos com os de Caiana dos Crioulos, mas os casamentos aconteciam desse modo apenas há décadas atrás. Essa tradição ainda é preservada em Caiana dos Crioulos porque nessa comunidade estes valores são preservados como uma marca da sua identidade.

Por considerarmos, com base em LEITE (1993) e BARTHES (1984) as fotografias fontes documentais de grande relevância, destacamos a seguir algumas imagens que retratam o casamento em Caiana e que transmitem momentos importantes experienciados por essa comunidade, por ocasião desse tipo de evento. Lembramos a força que têm essas imagens no sentido posto por Barthes, (p.13, 1984), quando este autor afirma: “o que a Fotografia reproduz ao infinito só ocorreu uma vez: ela repete mecanicamente o que nunca mais poderá repetir-se existencialmente.” É fato que os instantâneos que ilustram este texto possibilitarão diversas leituras e interpretações aos que realizam estudo na área. Contudo recomendamos considerar que eles não são a realidade em si, pois se fazem acompanhar do olhar e, por conseguinte das escolhas de quem faz o registro fotográfico, e, às vezes, até mesmo de quem se deixa fotografar. Cabe destacar, portanto, que

A fotografia impõe ao pesquisador sua visão do mundo - o enquadramento, a focalização a escala, os planos, os ângulos, a dispersão, a fixação, a granulação, o contraste a perspectiva. Como é imóvel e estática representa um tempo presente, um agora distante do qual o pesquisador é levado a reconstituir o que levou aquelas personagens a estar ali, assim, daquele jeito, naquele momento, para poder prever o desenlace, os momentos seguintes que podem vir a ser encontrados em outros instantes isolados, em outras fotografias. (LEITE, 1993, P. 17)

As fotos que ilustram este trabalho ensejam movimentos que se estendem da preparação à concretização do casamento, com grande envolvimento da comunidade na construção de uma "latada" feita com folhagens, galhos e troncos das árvores para abrigar as festividades, inclusive o forró que anima a noite do casamento; merece destaque também o local de preparação das comidas, situado nas proximidades da casa da noiva.

A própria construção da latada, a feitura das comidas, a arrumação da casa da noiva criam um clima de confraternização e de trocas entre os parentes e amigos que participam ativamente das diversas etapas que antecedem a festa. Essa movimentação não escapou aos flashes dos pesquisadores, parceiros e curiosos que já tiveram oportunidade de vivenciar os casamentos em Caiana. Esses 
registros iconográficos deixam para o (a) leitor (a) representações de um real vivo que é parte de um passado/presente: um acontecimento passado, um “isso foi”. Como nos lembra Barthes, (1984, p. 118) "mais vale dizer que o traço inimitável da fotografia (seu noema) é que alguém viu o referente (mesmo que se trate de objetos) em carne e osso ou ainda em pessoa."
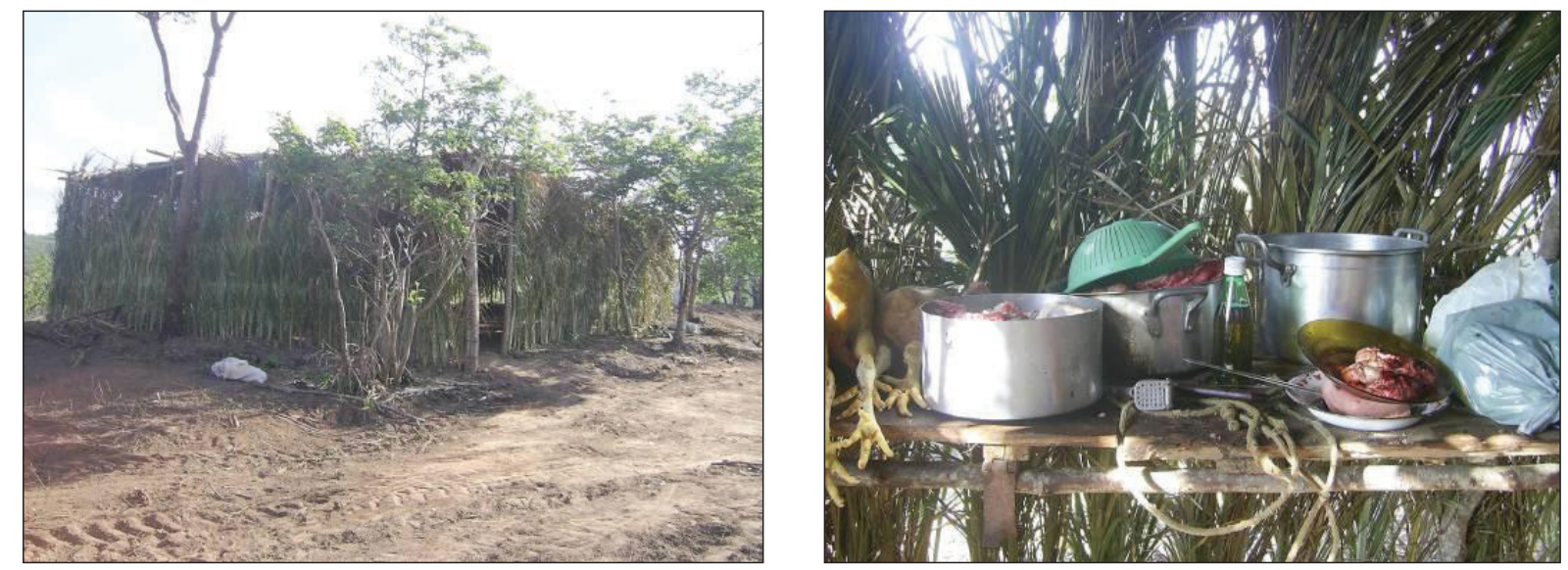

Figuras 1 e 2 - Latada para o forró e a "cozinha" construída para o casamento. Caiana dos Crioulos. Jan./2008. Moreira Alecsandra P. da C.
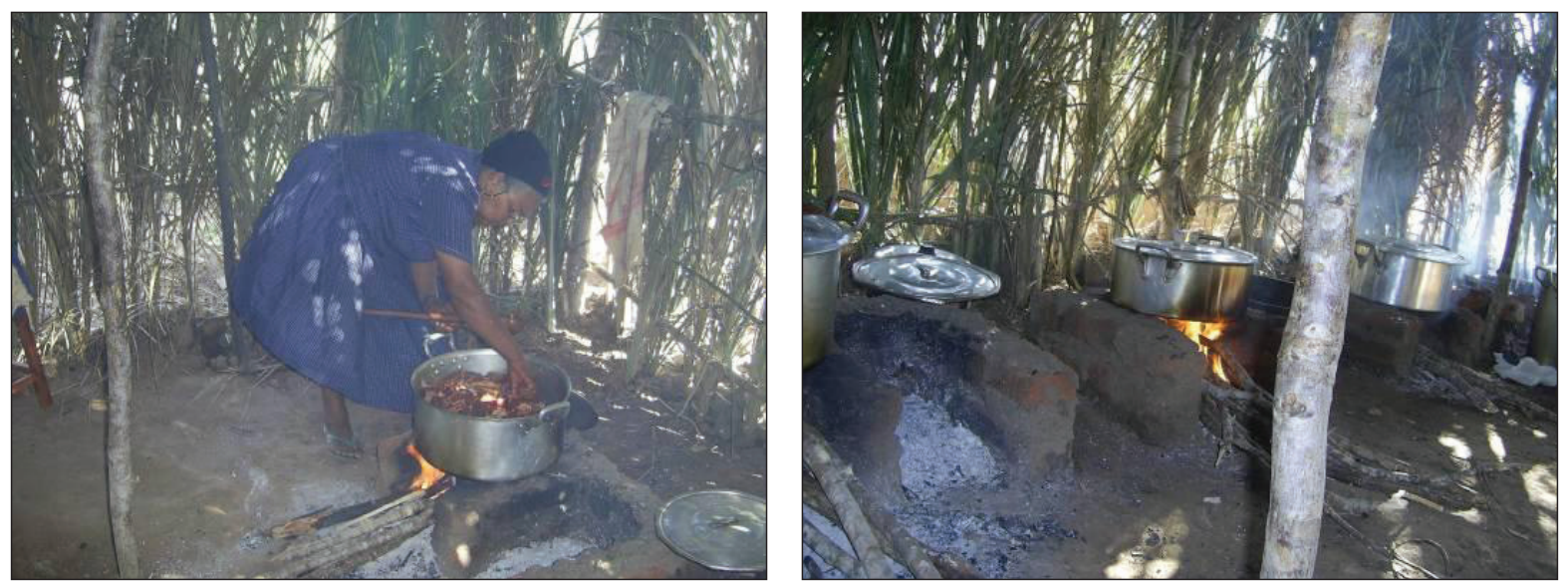

Figuras 3 e 4 - Local de Preparo das comidas. Caiana dos Crioulos. Jan./2008. MOREIRA Alecsandra P. da C.

Por fim -, cabe chamar a atenção: o casamento é apenas um dos acontecimentos que possibilita a discussão da identidade quilombola em Caiana dos Crioulos. No geral, as histórias sobre esse grupo étnico revelam desde filigranas memorialistas sobre suas origens até especificidades outras, registradas na culinária, nos folguedos, na música, estando portanto o território impregnado de lembranças e de marcas na paisagem. Essas marcas são consideradas no âmbito da ciência geográfica como geossímbolos conforme adverte Bonnemaison (2002, p. 124), para quem o espaço geossimbólico é "uma forma de linguagem, um instrumento de comunicação partilhado por todos e, em definitivo, o lugar onde se inscreve o conjunto da visão cultural". Sob esse prisma da leitura geográfica do espaço, podemos localizar em Caiana dos Crioulos diversas formas de linguagem que são partilhadas ora no âmbito familiar ora em coletivos, associações comunitárias, grupos de mulheres, de jovens, quando as pessoas se reúnem em prol de projetos políticos e organizativos, 
ora nas atividades cotidianas que marcam as suas vidas, mas é sobretudo nas marcas inscritas na paisagem do lugar, Caiana dos Crioulos, que elas se fazem anunciar: na distribuição das casas, na utilização dos quintais, no transporte e armazenamento da água, nas formas de cultivo, no preparo das comidas, na divisão do trabalho, na alegria brejeira das cirandas e cocos de roda. Nesses eventos e situações é que os geossímbolos tornam-se mais visíveis, possibilitando interpretações e diálogos com a abordagem cultural da Geografia que em Bonnemaison (2002 p. 106/107) ganha a seguinte interpretação:

Assim, entre a construção social, a função simbólica e a organização do território de um grupo humano, existe uma inter-relação constante e uma espécie de lei de simetria. A paisagem é um reflexo visual disso, mas toda uma parte permanece invisível porque ligado ao mundo subjacente da afetividade, das atitudes mentais e das representações culturais. Foi um pouco disso o que Sautter procurou definir, buscando a conivência secreta que liga os homens a sua paisagem, ao mesmo tempo mediadora e espelho de sua sensibilidade cultural. A paisagem conivência é, muitas vezes, o lugar de encontro e de uma emoção quase sensual entre os homens e a terra. O território toma aí todo o sentido que lhe foi atribuído por séculos de civilização campesina: ele é ao mesmo, raiz e cultura. Não é fortuito o fato de essas duas palavras terem o mesmo campo semântico e uma referência comum à terra nutridora.
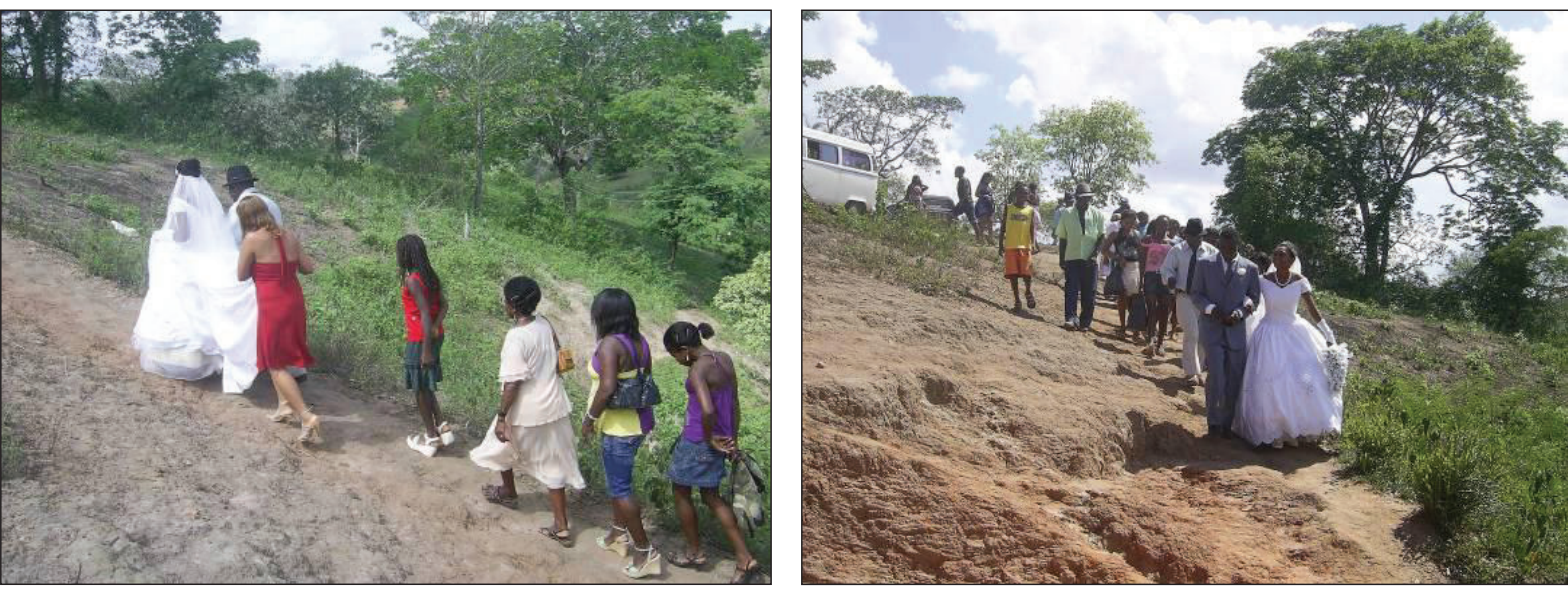

Figuras 5 e 6 - Noivos seguindo para a igreja Católica em Alagoa Grande e esperando os convidados que foram comprar os presentes, após a cerimônia religiosa. Caiana dos Crioulos. Janeiro de 2008. MOREIRA, Alecsandra P. da C.

A interpretação da terra e do território em BONNEMAISON (2002) traz elementos de um discurso humanista que nos lembra FRÉMONT (1974) e TUAN (1980) quando esses autores postulam uma leitura do espaço que compreende o lugar a partir da apreensão pelo sujeito do espaço vivido; interpretação que encontra âncora em Bachelard (1977, p. 18 ) que denomina topofilia “ as imagens do espaço feliz" que "Visam determinar o valor humano dos espaços de posse, espaços proibidos a forças adversas, espaços amados", ao mesmo tempo em que dialoga também com BERQUE (1998) em sua leitura sobre a paisagem cultural e entende como geo-grafia: a escrita da terra por um sujeito coletivo, a sociedade e, com Cosgrove (1998, p. 106) quando afirma: "todas as paisagens são simbólicas, apesar da ligação entre o símbolo e o que ele representa (seu referente) poder parecer muito tênue."

Nesta perspectiva é que fazemos a leitura das paisagens das comunidades quilombolas que pesquisamos. Elas trazem as marcas dos grupos sociais que as habitam e dos confrontos com a 
sociedade envolvente em seus interesses econômicos imediatos, trazem também a sua compreensão do mundo vivido, partilhado e reelaborado nos espaços familiares e coletivos.

Sobre a origem da comunidade de Caiana dos Crioulos, destacamos as hipóteses arroladas no Relatório de Identificação de Caiana dos Crioulos. Uma delas é a de que os primeiros habitantes teriam vindo do Quilombo dos Palmares em decorrência do massacre ocorrido nessa localidade; outra explicação veiculada (http://biblioteca.ibge.gov.br/visualizacao/dtbs/paraiba/alagoagrande. pdf ) é a de que negros desembarcados na Baía da Traição teriam fugido de um navio negreiro, indo isolar-se naquela região serrana, seguindo o curso do Rio Mamanguape que passa pela cidade de Alagoa Grande. Além destas explicações, há ainda o argumento de que esse quilombo teria sido conseqüência da campanha abolicionista ocorrida no município de Areia, onde foi facilitada a fuga e concedida a libertação a escravos.

Os pesquisadores Paiva e Souza (1998) no Relatório de Identificação de Caiana dos Crioulos afirmam que a comunidade está situada no antigo "Sertão do Paó." E que sertão será esse? Provavelmente trata-se de uma das rotas empreendidas por Bandeirantes em busca da ocupação de terras e da preação indígena tão comum no século XVII. Apoiados na historiografia regional, os pesquisadores que produziram o laudo antropológico afirmam que data de 1620 as primeiras casas e fazendas situadas às margens da Lagoa do Paó. Entretanto somente entre 1719 e 1767 se deu a colonização do município de Alagoa Grande com as concessões de terras a Domingos da Rocha, Isidoro Pereira Jardim, Marinho Gomes, Agostinho de Jesus e ao Padre Luis Quaresma Dourado, que iniciaram o plantio da cana-de-açúcar, nas baixadas e vales, e o algodão nas encostas.

Outro registro da origem da comunidade fartamente comentado por MOREIRA (2006), está presente na memória musical da Paraíba no volume 1 do CD de Caiana dos Crioulos, Ciranda, Coco de Roda e outros cantos, onde vislumbramos também muitos traços da cultura da comunidade. Na análise que fazem dessa memória MOREIRA E RODRIGUES (2006), destacam versos das canções: "Corresse Nego" e "A Lavadeira".

O território de Caiana dos Crioulos, embora possua uma área onde habitam os caianenses desde tempos remotos, contando com o reconhecimento da sociedade envolvente, não tem regularizada a área que reivindica para trabalho. As 120 famílias que habitam a localidade contam apenas com os quintais que usam para alguns pequenos cultivos e, com a criação de animais de pequeno porte. Para plantarem áreas mais extensas, deslocam-se para as circunvizinhanças onde trabalham em regime de parceria, pagando a terça parte da sua produção aos proprietários de terras do município de Alagoa Grande.

Cabe mencionar que as lutas históricas por terra na região, cuja memória se deixa anunciar em movimentos como Ronco da Abelha, Quebra-quilos e Ligas Camponesas, não conseguiram impedir que o poder político e econômico abarcassem e regularizassem terras de posseiros, inclusive as que tradicionalmente plantavam os caianenses em regime de parceria. Com o acirramento das lutas pela terra, no final da década de 1980 e início da década de 1990, em prol da Reforma Agrária, sob a liderança de Margarida Maria Alves, de outros sindicalistas e de setores da igreja católica, ocorreu a desapropriação de algumas propriedades que deram origem a áreas de assentamento, num total de 13 assentamentos localizados em Alagoa Grande. Naquele momento os caianenses ainda não tinham pleno conhecimento dos seus direitos, e terras contíguas à área que ocupavam historicamente e que poderiam ter sido demarcadas para este grupo social, deram origem a assentamentos rurais, dificultando ainda mais o acesso a terra a este grupo étnico. A esta questão de grande envergadura, que desafia cotidianamente o INCRA a encontrar solução para o problema, outras comparecem no interior do próprio grupo em decorrência de disputas políticas, interpretações da cultura familiar, das relações de parentesco, das tendências religiosas e político-partidárias e de nuances que marcam o processo identitário da cultura afrodescendente. São questões, via de regra, acionadas por agentes sociais negros (as) e partícipes dos movimentos sociais, de modo especial destacamos as ONG's que por vezes disputam a condução de ações que, se por um lado viabilizam processos de 
formação e discussões políticas, por outro dificultam a autonomia e o protagonismo desses grupos étnicos. Somando-se a essas organizações, tem-se a presença de pesquisadores de diversas áreas das Ciências Humanas e Sociais, artistas e educadores que também contribuem em seus contatos para despertar práticas políticas e disputas, colocando em cena debates antes silenciados por visões hegemônicas impostas pela cultura branca. Podemos dizer que na interface em que atuam pesquisadores, técnicos e animadores culturais há visões de mundo díspares e, por vezes até conflituosas desses agentes externos que atuam em Caiana, fato que se repete também em todas as comunidades que pesquisamos, o que exige posicionamentos para os quais as comunidades quilombolas pesquisadas ainda não amadureceram ou, não acharam conveniente se manifestar.

\section{PITOMBEIRA: história e memória se entrelaçam à trajetória de Mateus Velho}

O topônimo Pitombeira, partilha da identidade do lugar e se confunde com a história dos (as) negros(as) que residem na localidade, visto que se associa à existência de uma árvore, uma Pitombeira (Talisia esculenta) Sapindaceae, situada às margens do rio Quixaba. A comunidade criou na convivência próxima com essa árvore uma fronteira que aos poucos foi sendo assimilada pelos "de dentro" e pelos "de fora", visto que comumente passaram a ser chamados pelos moradores de Várzea e de Santa Luzia de pessoal da Pitombeira ou negros (as) da Pitombeira. O topônimo foi por eles preservado, guardando grande associação com a própria história das famílias; neste sentido a árvore Pitombeira, se interpretada à luz do que sugere BONNEMAISON (2002), pode ser considerado um geossímbolo para a comunidade pesquisada.

Em Pitombeira, a memória da comunidade narrada pelo Sr. Ladislau Ricarte da Silva, (94 anos), vulgo Lalau, o mais idoso da comunidade, dá-se num tom épico.O Sr Ladislau apresenta perda da visão provocada, segundo ele, pela extração de xelita. Ele e sua esposa Dona Geraldina afirmaram que o local, onde vivem com sua descendência, surgiu de forma oculta. Ao chegar ali os casais de negros Inácio Félix, Severino, Simplício e Gonçalo Fogo, sobre os quais ouvimos especulações de que seriam escravos fugidos e que traziam junto consigo suas esposas, construíram casas de taipa e formaram sua prole que aos poucos deu origem a Pitombeira. Rodeado por seus familiares e representando três gerações - netos, bisnetos e tataranetos - ouvimos, por duas vezes, em aulas de campo, esse senhor a narrar algumas das suas histórias familiares. Segundo o Sr. Ladislau um desses quatro negros, o Severino, era o seu tataravô, ele era sapateiro, mas trabalhava também no roçado onde plantava milho e feijão; já Gonçalo Fogo, era o bisavô de sua esposa, Dona Geraldina.

Da união do Sr Ladislau com D. Geraldina nasceram quatro filhas: Inácia, Izidra, Maria e Juliana que hoje já se agregam as três gerações seguintes.

Disse o entrevistado que o primeiro ancestral da comunidade, Mateus Velho, ao chegar à localidade, onde viveu com sua esposa, abrigou outros escravos. Essa narrativa comparece na voz de Antonia Cristina, professora aposentada, residente em Santa Luzia, município do qual se desdobrou Várzea, onde se situa Pitombeira. A professora Antonia Cristina possui vínculos parentais com a comunidade e é uma das responsáveis pela mobilização em torno da construção da identidade quilombola e da solicitação da certidão à Fundação Palmares.

Nas referências acadêmicas, a história ganha similitude com os relatos orais registrados em Pitombeira. Segundo NÓBREGA (2007), a Comunidade de Pitombeira começa a existir aproximadamente em 1850, onde o ex-escravo Matheus Velho (africano) alforriado pelo Capitão "Neco da Ramadinha", recebe uma porção de terras da sobra da Data de Mocó com o Sítio Tamanduá em Santa Luzia do Sabugi (antigo nome da atual Santa Luzia - PB), fixando-se nessa localidade com sua esposa Justina. Após algum tempo Matheus Velho deu proteção aos escravos fugidos Inácio Félix, Severino, Simplício e Gonçalo Fogo, todos trazendo suas esposas, e entre 1875/76, aparece o negro Izidro que também permaneceu protegido por suas qualidades de trabalhador, manso e ordeiro. 
Do que ouvimos em fragmentos, das lembranças que se repetem nas falas dos mais jovens e com base em NÓBREGA (2007), temos a seguinte compreensão: a localidade de Pitombeira surgiu por volta do ano de 1850, quando o escravo alforriado Matheus Velho recebeu doação de terra na cidade de Santa Luzia de Sabugi (atual Santa Luzia - PB) na qual passou a habitar com sua esposa. Dada a sua condição de ex-escravo deu guarida a alguns outros ex-excravos.

\section{CONTANDO OS FEITOS, “POIS NA ESCOLA NUNCA CONTAMOS AOS NEGROS OS SEUS VALORES"...}

A comunidade de Pitombeira possui aproximadamente 52 famílias, contabilizando cerca de 172 pessoas. Dentre as atividades que desenvolvem está a prática da agricultura, no período chuvoso, a apicultura e o artesanato em palha, tendo como matéria-prima a carnaúba. No entanto, a principal fonte de renda da comunidade provém da aposentadoria e de programas sociais como o Bolsa Família. Segundo MACENA (2008), foram implementados na comunidade pelos gestores públicos alguns programas com o objetivo de melhorar a qualidade de vida dos moradores, como a construção de poços artesianos, cisternas, reconstrução das casas de taipa em alvenaria, construção de sanitários e fossas, distribuição de cestas básicas

No que concerne à educação e à saúde, a comunidade possui uma escola municipal da $1^{\mathrm{a}}$ à $4^{\mathrm{a}}$ série, construída na década de 1980, embora não haja uma proposta pedagógica voltada para a valorização da cultura afrodescendente, conforme foi possível observar nos contatos realizados. Além disso, não há posto de saúde na comunidade, os atendimentos médicos são prestados em Várzea, sede municipal, ou em Santa Luzia.

Percebemos que os principais problemas apontados inclusive por Joseildo Souza, presidente da associação Comunitária, dizem respeito à escassez de água, à falta de trabalho e à ausência de um posto de saúde. Sobre isso, dona Maria da Conceição Silva Dias, professora da comunidade esclarece:

São muitas as dificuldades. Principalmente água, a comunidade é muito escassa, não tem água, os barreiros que tem são muito pequenos, a água que é acumulada nesses reservatórios só dá pra três, quatro, cinco meses no máximo. Então, quando essa água se acaba fica muito distante pra gente pegar. Porque quando essa água acaba a gente pega água de um açude da comunidade vizinha que é muito distante, e é puxada através de animal em carroça. Tem várias dificuldades aqui na comunidade, não tem posto de saúde, se você precisar fazer uma consulta precisa se deslocar até a cidade de Várzea, sem saber se tem o médico lá no dia. Fonte: Gestar: território, trabalho e cidadania - Grupo de pesquisa do CNPq.

No que diz respeito à questão étnica e à identidade, os (as) entrevistados (as) se reconhecem como negros, negras, no entanto, cada um ao manifestar seu entendimento sobre sua identidade, revela, sob diferentes ângulos, as marcas dos discursos escolares, das práticas sociais, dos conflitos interétnicos comumente obscurecidos pelo discurso da democracia racial. Os depoimentos citados a seguir denotam tensões no grupo. Quando não explicitamente, o preconceito é citado nas entrelinhas e neste sentido é que mencionamos as discordâncias com a sociedade envolvente.. Sobre o tema ouvimos de uma educadora e quilombola a seguinte opinião:

Eu sou negra. O ser humano, o negro, o descendente dos africanos, ele sempre sofre [preconceito], porque muitas vezes não é aceito, embora, que muitas vezes porque ele mesmo se discrimine. Quando alguém me chama de negra e eu não aceito ser negra, ser preta, então eu mesma estou me discriminando. Isso acontece muito, não só aqui, mas em todos os lugares. Nas escolas principalmente, porque jamais você vê uma noiva de uma escola, de uma quadrilha, muitas vezes nunca vê ser escolhido aquela criança negra, sempre é mais escolhido aquela criança mais bonita, que se destaque na sala, não é isso? Mas será que aquela criança negra talvez tenha tanta vontade de ser uma noiva de uma quadrilha, e muitas vezes nós professores às vezes até discriminamos isso e nem percebemos. (....) Muitas vezes, nós 
na escola nunca contamos ao negro os seus valores e sim os seus defeitos, contamos como escravos. Depoimento de Maria Conceição registrado em trabalho de campo. Fonte: Gestar: território, trabalho e cidadania - Grupo de pesquisa do CNPq

Outras opiniões ouvidas revelaram visões pessimistas e um certo tom de descrença nos políticos e nas políticas públicas:

Tudo que vem pra aqui pra dentro dos quilombolas, os políticos passam a mão. Olhe, tinha uma passagem molhada pra vim pra aqui, passaram a mão, levaram lá pra fazenda do ex-prefeito. Vinha uma mina pra cá, passaram a mão também, o Efraim Moraes. Acham que ele é o Deus do mundo, mas ele não é, mas passou a mão também. Por isso, eu sou uma pessoa realista, esses quilombolas, eu não participo de nada neles, porque o que vem pra aqui os políticos passam a mão.

Depoimento de dona Maria Madalena registrado em trabalho de campo.

Fonte: Gestar: território, trabalho e cidadania - Grupo de pesquisa do CNPq

Este tipo de depoimento é recorrente nas comunidades quilombolas. Reclama de desvio de verbas, apropriações indébitas, atrasos nos repasses de recurso, obras inconclusas, o que legitima a descrença nos políticos e nas políticas públicas.

Os enfrentamentos cotidianos não obscurecem, no entanto, os relatos memorialistas que de per si trazem á tona as ações de trabalho, os folguedos, os rituais religiosos como marcas identitárias.

O Sr. Ladislau ao recordar os tempos de sua juventude vividos em Pitombeira, descreve com entusiasmo como eram os casamentos naquela época.

Aqui [nas festas de casamento] era três dias de festa, de baile. Nego bebendo, dançando, fumando. A luz era de fogo na telha, a gente fazia o fogo, junta a lenha, bota na telha e bota fogo e vamo dançar, aí é que era o forró gostoso. Os tocador vinha de fora, vinha de Santa Luzia, desses lugarzinho, qualquer um, um folinho pequeno assim e a negada travava, passava dois três dias dançando (...). Coco de roda... dancei muito coco de roda.

Misto de sagrado e profano, as festas de casamento nas comunidades quilombolas nos fazem recordar o que afirma WOLF (1970) sobre campesinato e religião. Para esse autor a religião forja mais um elo que liga o campesinato à ordem social envolvente. Há, portanto, diferentes eventos nessas comunidades onde o sentimento religioso ganha expressão. Daí que ao ser indagado sobre os seus vínculos religiosos, o Sr. Ladislau se disse católico e destacou que a maioria da população da Pitombeira é católica; alguns vão à missa em Santa Luzia, já que na localidade não há igreja. Destaca, todavia que isso não inviabiliza as orações, pois no mês de maio fazem as novenas na própria Pitombeira e essa prática reúne todas as faixas etárias da localidade.

Cabe destacar que não foi possível registrar se em Pitombeira há práticas e rituais religiosos pautados em matrizes africanas. Soubemos da existência de evangélicos, mas não foi possível abordar a religiosidade sob nenhum aspecto, visto que o tema demanda sutilezas em sua abordagem o que só é possível concretizar-se mediante contatos mais prolongados.

Sobre o trabalho na comunidade, o Sr. Ladislau disse que eles trabalhavam de toda maneira, que lá "não tinha preguiçoso não", e que trabalhavam principalmente na agricultura. Lembrou inclusive de práticas cotidianas que revelaram a criatividade e a adoção de estratégias de sobrevivência dos negros, em situações de crise. Nesse sentido nos disse que nos períodos de seca, queimava-se o xiquexique pra comer, Além disso, conta com entusiasmo que

Os nego velho eram muito inteligente, viu? Aí ganhava o mato a cortar faveleira, pinhão. Aí cortava, botava no fogo, queimava, aí tirava as cinza, viu? Aí, colocava aquelas cinza numa lata e botava pra quarar, depois que quarava aí botava água dento. Aí aquilo ia apurando, apurando, apurando e quando dava fé tava aquele bolão de sebo, aí vamo pro fogo pra fazer o sabão. E fazia o sabão, sabão da terra, viu? 
Chamou a atenção em todas as situações de contato com o Sr Ladislau, o tom de tristeza com que se reportou à exploração do trabalho, ao relembrar que trabalhou muito tempo com mineração de xelita; tanto tempo que perdeu a visão por causa do contato com esse mineral.

Nessa atividade o pagamento era feito com base na quantidade de minério extraída. O que nos leva a crer que os trabalhadores eram submetidos a longas jornadas de trabalho e ao contato direto com o mineral, sem as devidas proteções.

Ao final da entrevista, o Sr. Ladislau lamentou-se por não poder mais enxergar, relembrou com nostalgia do seu tempo de juventude, mas nesse ínterim foi reconfortado por sua esposa que lhe dizia: "na vida a gente tem que chegar nesse ponto." D. Geraldina falava da inexorabilidade das perdas que traz a velhice; revelava, porém desconhecimento da expropriação a que estiveram submetidos ela, o Sr. Ladislau, seus filhos e os seus ancestrais, cujos direitos foram historicamente negados. Contrariamente ao que foi relatado ocorre aos poucos com os mais jovens da comunidade, pois já se revelam na família da $\mathrm{D}$. Geraldina e na vizinhança, lideranças políticas que acenam com novas esperanças e compromissos com a reparação de direitos que lhes foram negados.

\section{PARATIBE: memória em migalhas, território em disputa}

A certificação de Paratibe, comunidade quilombola inserida no município de João Pessoa, no bairro Valentina Figueiredo, data de 11 de julho de 2006. A memória aponta o ajuntamento de negros (as) em decorrência da presença nas imediações de antigas fazendas como a de Mangabeira que deu origem ao bairro de Mangabeira e a Fazenda Cuiá, situada dentro do perímetro urbano de João Pessoa. A comunidade possui aproximadamente 130 famílias que trabalham no comércio e como prestadores de serviços.
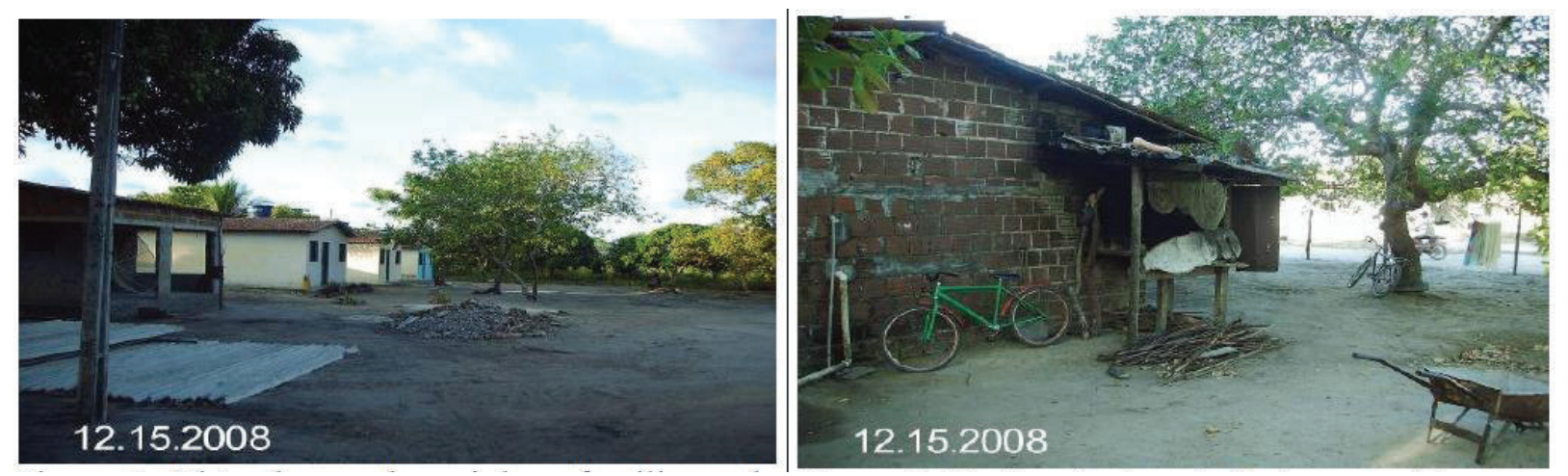

Figuras 7 e 8 - Vista dos núcleos familiares de moradores da comunidade (à esquerda) e Fogão a lenha, ainda é uma prática entre a comunidade (à direita).

Fonte: Gestar, dezembro de 2008

A pressão resultante da especulação imobiliária atingiu fortemente a comunidade e provocou danos em sua organização familiar e territorial, pois como afirma MACENA (2009 p.65). ."A especulação imobiliária seduz as famílias a venderem as suas propriedades transformando-as em loteamentos. Questão que já havia sido colocada por Cavalcante, (2007, p. 57), quando destaca:

[...] já a partir do fim da década de 1970 e começo da década de 1980 começaram a chegar pessoas para o norte de Paratibe comprando pequenos lotes de terras dos Miguel. A partir de então, Paratibe começa a se urbanizar. Pessoas dos bairros de Valentina Figueiredo e Mangabeira como também de outros bairros e até mesmo pessoas de outros municípios mais distantes começam a se instalar e a malha urbana começa a tomar conta da paisagem agrária $[\ldots]$ 
As leituras da paisagem com base em fotografias aéreas ou cartas topográficas relativas a essa área revelam que até a década de 1970 ela era marcadamente rural. Conforme ratifica Macena (2009,p.68):

Os moradores, especialmente os mais jovens, não têm clareza acerca dos limites territoriais da comunidade, mas guardam algumas lembranças acerca de histórias contadas por seus ancestrais que revelam ter sido parte de suas terras ocupadas por pessoas de fora via especulação imobiliária. Essa ocupação por parte de estranho ocorreu porque ao longo da história de organização social dos primeiros habitantes da comunidade, não havia a preocupação em delimitar o território.

A questão da propriedade da terra está no centro dos debates sobre a garantia dos direitos consagrados na Constituição de 1988 e somente o acesso pleno à terra assegurará a reprodução material e cultural desses povos.

No caso de Paratibe, o processo de construção do laudo antropológico está em curso e a demarcação urge em decorrência da pressão que exerce o mercado imobiliário naquela localidade.

Por fim a Comunidade Negra de Paratibe expressa de forma singular sua reprodução sócio-espacial, que se traduz no uso e ocupação da terra e nos conflitos latentes em decorrência de fatores externos que influenciaram as mudanças no modo de vida local. Merece destaque disputas internas e externas como a questão do avanço da malha urbana e a redução da área cultivável; a luta por interesses em comum entre moradores da comunidade, inclusive os conflitos que têm origem na aceitação ou na recusa da sua condição de remanescente de quilombo, além das dificuldades que enfrentam na viabilização de projetos de interesse comum e na leitura que fazem das perspectivas futuras.

\section{DA CERTIFICAÇÃO À DEMARCAÇÃO: situação atual das comunidades quilombolas na Paraíba}

De acordo com a Comissão Estadual das Comunidades Negras e Quilombolas da Paraíba (Cecneq) foram identificadas no Estado da Paraíba 32 comunidades quilombolas. Dessas comunidades, 28 já foram reconhecidas pela FCP entre o período de 2004 e 2008, as outras foram identificadas e, segundo a antropóloga Maria Ester Pereira Fortes, contam com o apoio de algumas entidades, como a Cecneq e a Associação de Apoio aos Assentamentos e Comunidades Afro-descendentes (AACADE/PB), no desenvolvimento de todo o processo de demarcação das áreas quilombolas. A mesma técnica nos informou que este órgão tem uma parceria com antropólogos da Universidade Federal de Campina Grande (UFCG), além de contarem com a assessoria de uma antropóloga do Acre para trabalharem juntas na construção do relatório de três comunidades quilombolas: Caiana dos Crioulos, situada no município de Alagoa Grande, que mesmo em 2010 tendo completado doze anos que obteve a certidão da FCP ainda não conseguiu a posse da terra de trabalho; Bomfim, situada no município de Areia, que já obteve a demarcação de suas terras e, a comunidade Grilo situada no município de Riachão do Bacamarte que está com o processo de demarcação em curso. A respeito das ações em curso nas comunidades já identificadas, ela afirmou que as que estão em fase mais avançada do processo administrativo são as comunidades: Bonfim, localizada no município de Areia, Talhado, localizada no município de Santa Luzia, Paratibe, comunidade urbana localizada na capital João Pessoa, Grilo ,localizada no município de Riachão do Bacamarte, Matão, localizada no município de Gurinhém, e Pedra D'água, localizada no município de Ingá,.

Destacamos no quadro I a situação atual, novembro de 2010, das comunidades quilombolas da Paraíba. 
Quadro 1 : Comunidades Quilombolas na Paraíba.

\begin{tabular}{|c|c|c|c|}
\hline \multicolumn{2}{|c|}{$\begin{array}{c}\text { NOME DA COMUNIDADE / } \\
\text { № DE FAMÍLIAS }\end{array}$} & \multirow{2}{*}{$\begin{array}{l}\text { MUNICíPIO } \\
\text { João Pessoa }\end{array}$} & $\begin{array}{l}\text { LOCALIZAÇÃO/ } \\
\text { MESORREGIÃO }\end{array}$ \\
\hline Negra Paratibe & 100 & & \multirow{5}{*}{ Zona da Mata Paraibana } \\
\hline Mituaçu & 225 & \multirow{4}{*}{ Conde } & \\
\hline Ipiranga & 50 & & \\
\hline Com. Negra Gurugí & 253 & & \\
\hline Mata da Chica & - & & \\
\hline Matão & 28 & Mogeiro & \multirow{10}{*}{ Agreste Paraibano } \\
\hline Vertente & - & \multirow{3}{*}{ Alagoa Grande } & \\
\hline Caiana dos Crioulos & 140 & & \\
\hline Zumbi & - & & \\
\hline Engenho Bonfim & 22 & \multirow{2}{*}{ Areia } & \\
\hline Engenho Mundo Novo & - & & \\
\hline Cruz da Menina & - & Dona Inês & \\
\hline Grilo & 80 & Riachão do Bacamarte & \\
\hline Negra do Sítio Matias & 50 & Serra Redonda & \\
\hline Pedra D’água & 120 & Ingá & \\
\hline Sussuarana & - & \multirow{3}{*}{ Livramento } & \multirow{6}{*}{ Borborema } \\
\hline Areia de Verão & - & & \\
\hline Vila Teimosa & - & & \\
\hline Pitombeira & 50 & Várzea & \\
\hline Serra do Talhado & 40 & \multirow{2}{*}{ Santa Luzia } & \\
\hline Com. Talhado Urbano & 200 & & \\
\hline Com. Rural Negra Lagoa Rasa & 32 & \multirow{3}{*}{ Catolé do Rocha } & \multirow{16}{*}{ Sertão Paraibano } \\
\hline Curralinho/Jatobá & 38 & & \\
\hline São Pedro dos Miguéis & 38 & & \\
\hline Com. Negra de Santa Tereza & 150 & \multirow{3}{*}{ Coremas } & \\
\hline Com. Negra de Barreiras & 54 & & \\
\hline Com. Negra de Mãe D’água & 125 & & \\
\hline Umburaninhas & 18 & \multirow{2}{*}{ Cajazeirinhas } & \\
\hline Vinhas & 15 & & \\
\hline Barra de Oitis & - & \multirow{2}{*}{ Diamante } & \\
\hline Sítio Vaca Morta & - & & \\
\hline Com. Negra Contendas & 38 & São Bento & \\
\hline Triunfo & - & Triunfo & \\
\hline Sítio Livramento & 39 & São José de Princesa & \\
\hline Domingos Ferreira & 90 & Tavares & \\
\hline Fonseca & - & Manaíra & \\
\hline Serra Feia & 150 & Cacimbas & \\
\hline
\end{tabular}

Fonte: INCRA - SR/PB e Fundação Cultural Palmares.

Organização: RODRIGUES, M. de F. F.; MARACAJÁ, M. S. L.; ALMEIDA, M. P de.

Na mesma entrevista com a antropóloga do Serviço de Regularização de Territórios Quilombolas do INCRA, Maria Ester Pereira Fortes, ouvimos o relato sobre as dificuldades para demarcação das terras quilombolas na Paraíba, especialmente a partir da publicação da Instrução Normativa - IN n ${ }^{\circ}$ 49 de 29 de setembro de 2008, que especifica os procedimentos para identificação, reconhecimento, delimitação, demarcação, desintrusão, titulação e registro das terras ocupadas por remanescentes 
das comunidades dos quilombos de que tratam o Art. 68 do Ato das Disposições Constitucionais Transitórias (ADCT) da Constituição Federal de 1988 e o Decreto n 4.887, de 20 de novembro de 2003.

A despeito da quantidade de comunidades quilombolas já certificadas na Paraíba, cabe destacar que as exigências postas pela Instrução Normativa - IN 49/2008 constituem-se em verdadeiros desafios à regularização dessas terras. Além disso, os projetos desenvolvimentistas alavancados pelo Programa de Aceleração do Crescimento (PAC) chegam, por vezes, desconhecendo demandas seculares, quando visam atender a pleitos de políticos e oligarquias locais em detrimento de interesses das populações tradicionais. Cito como exemplo a proposta de construção de uma barragem nas imediações da comunidade de Caiana dos Crioulos. Este projeto inviabiliza a demarcação e titulação de uma área incluída no memorial descritivo feito pela equipe Serviço de Regularização de Territórios Quilombolas do INCRA-PB, que poderia solucionar a demanda por terra dessa comunidade.

\section{CONSIDERAÇÕES FINAIS}

Ciente da complexidade que envolve as relações camponesas destacamos ao longo deste ensaio, na interpretação dos territórios quilombolas, as dimensões materiais e simbólicas que lhes conferem uma identidade étnica, considerando o corpo como uma fronteira, como suporte de signos sociais que dão identidade a distintos grupos e aos indivíduos que neles vivem, no contexto de uma sociedade que pratica o preconceito racial, mas sem perder de vista que a terra cultivada, a paisagem, as relações de poder construídas se põem como elementos definidores da territorialidade camponesa verbalizada em diversas situações em que se relacionam as comunidades de Caiana dos Crioulos, Paratibe e Pitombeira com a sociedade envolvente, de modo especial na luta pela demarcação das terras onde vivem e trabalham e, onde viveram e trabalharam seus ancestrais.

Consideramos as especificidades da terra camponesa e quilombola a partir das leituras de autores das Ciências Humanas e Sociais que reconhecem a condição de exclusão dos negros (as) privado(as) das condições básicas de sobrevivência, portanto de direitos fundamentais, ratificados pelo Estado brasileiro na Constituição de 1988.

Embora a condição de exclusão a que estão submetidas as comunidades quilombolas na Paraíba sejam evidentes, cabe assinalar alguns avanços inquestionáveis do Estado brasileiro na promulgação de leis que fundamentam a perspectiva de criação de uma cultura política que busca consolidar-se tendo como parâmetro a ética, a valorização da democracia e o respeito à diferença. Neste sentido lembramos o que adverte Bobbio (1997, pp. 69-70), sobre o papel dos intelectuais na produção do conhecimento, quando afirma: "Nosso problema não é o de saber se os intelectuais são rebeldes ou conformistas, livres ou servis, independentes ou dependentes, mas de trocarmos algumas idéias sobre o que os intelectuais que se reconhecem em uma determinada parte política fariam ou deveriam fazer".

É com o propósito de demarcar uma posição como geógrafa e como cidadã que refletimos sobre as comunidades quilombolas, sem jamais esquecer que com este exercício, reconhecemos, concordando com ALMEIDA (2009), ser o estudo geográfico uma representação do mundo, pois se refere a fenômenos vistos por um ângulo determinado. Com essa mesma compreensão acerca da interpretação geográfica, foi que nos propusemos a sistematizar este texto em busca de diálogo com a própria Geografia e com outros campos do saber, ciente que todo texto comporta os limites de sua época e de seu intérprete.

Cabe destacar que as manifestações culturais dos (as) negros (as) constituem-se em filigranas às pesquisas contemporâneas, pois relembram com cânticos e danças, através de músicas ou poesias que embalam suas atividades de trabalho, os desafios cotidianos, traduzindo por meio dessas manifestações culturais a sua relação com a terra como lugar de reprodução da vida; anunciam também a fé nos santos padroeiros e revelam a dor originária de perdas diversas do seu povo, que em saudosismos desvelam seus vínculos com a mãe África. 
Ao trazermos a cultura para o centro do debate na interpretação do território, reafirmamos o que já anunciaram outros geógrafos a exemplo de CLAVAL (2001), HAESBAERT (1999), ALMEIDA (2009) bem como historiadores e cientistas sociais dentre outros estudiosos, sobre a legitimidade desses fundamentos na interpretação da realidade. Assim sendo os cocos de roda e as cirandas são folguedos de grandes simbolismos, mas são também verdadeiros hinos da resistência e instrumentos de denúncia para os negros (as). Por isso, via de regra, os que visitam as comunidades afrodescendentes são recepcionados com rituais que demarcam claramente a identidade étnica do grupo. A consciência da cultura como patrimônio, nos leva a tomar as dimensões simbólicas da construção territorial como referência à Geografia, pois sabemos que o território comporta em si vários sentidos e um deles é o sentido simbólico que conduz e possibilita o fortalecimento das territorialidades e do sentimento de pertencimento ao território, ao lugar, a região e, até mesmo a nação.

Ao finalizarmos esta reflexão cabe destacar que para as comunidades quilombolas a memória é um importante componente na construção da identidade, pois é através dela que as práticas culturais se mantêm vivas e revigoram a trajetória de luta e de resistência desses grupos étnicos, seja quando eles se organizam em associações, partidos políticos dentre outros, seja quando dançam o coco, a ciranda, celebram casamentos, batizados dentre outras práticas religiosas de matriz católica ou africana.

Cabe, portanto, assinalar com base em Le Goff, (1996, p. 477) que a memória onde cresce a história, que por sua vez a alimenta, procura salvar o passado para servir o presente e o futuro. Devemos trabalhar de forma que, a memória coletiva sirva para a libertação e não para a servidão dos homens." É com este propósito que trazemos as paisagens como geossímbolos como referência à demarcação dos territórios quilombolas. Com esta proposição acreditamos estar colaborando para que a memória social seja respeitada e, a reprodução sócio-espacial se concretize na perspectiva da ascensão de um novo sujeito de direito, com acesso aos bens materiais e ao patrimônio cultural com os quais se identifica. Assim, a abordagem cultural da Geografia enseja o respeito aos direitos humanos, seja na igualdade, seja na alteridade.

\section{REFERÊNCIAS BIBLIOGRÁFICAS}

ALMEIDA, M. G.Territorialidades na Amércaa Latina. Goiânia: UFG, 2009.

ANDRADE, M. C. de. A questão do Território no Brasil. São Paulo: Hucitec, 1995.

ANJOS, R. S. A. dos. (Pesq.). Quilombolas: tradições e cultura de resistência, São Paulo: Aori Comunicação, 2006.

ANJOS, R. S. A. O espaço geográfico dos remanescentes de antigos quilombos no Brasil. Terra Livre, São Paulo, n. 17, p. 139-154, $2^{\circ}$ semestre, 2001.

ARRUTI, J. M. Emergência dos "remanescentes": Nota para o diálogo entre indígenas e quilombolas. In: MANA. Vol.3; Rio de Janeiro, 1997 ISSN:0104-9313. Disponível em: $<$ http://www.scielo.br $>$. Acesso em 13/11/2005.

BACHELARD, G. A Formação do Espírito Científico. Rio de Janeiro: Contraponto, 1996.

BACHELARD, G.. A Poética do Espaço. Rio de Janeiro: Livraria Eldorado Tijuca Ltda., 1977.

BARTHES, R. A Câmara Clara: nota sobre a fotografia. Rio de Janeiro: Nova Fronteira, 1984.

BERQUE, A. Paisagem-Marca, Paisagem-Matriz: elementos da problemática para uma Geografia Cultural. In: CORRÊA, R.L. et al. (Orgs). Paisagem, Tempo e Cultura. Rio de Janeiro: EdUERJ, 1998.

BONNEMAISON, J. Viagem em Torno do Território. In: Corrêa, R e Rosendahl, Z. (orgs.) Geografia Cultural: Um Século (3).Rio de Janeiro: EdUERJ, 2002.

BOSI, A. Colônia, Culto e Cultura. In: Dialética da colonização. São Paulo: Companhia das Letras, 1992. BRUNO, R.A.L. Nova República: a violência patronal como prática de classe. Sociologias, Porto Alegre: ano 5, n. 10, jul/dez 2003. p. 284-310. 
CAIANA DOS CRIOULOS (ciranda, coco de roda e outros cantos). Memória Musical da Paraíba. Volume 1. Gravado em Caiana dos Crioulos, em 02 de abril de 2003.

OLIVEIRA, B. A.C.de C.. Patrimônio Cultural: saberes e usos da Floresta.. In ALMEIDA, Maria Geralda. Territorialidades na Amérida Latina. Goiânia: UFG, 2009.

CAVALCANTE, Y. Y. de L, Paratibe: herança quilombola e reorganização do espaço agrário-PB. (Monografia de Graduação); UFPB, João Pessoa, 2007.

CLAVAL, P. A Geografia Cultural. Florianópolis: Editora da UFSC, 2001.

COSGROVE, D. A Geografia está em toda parte: Cultura e simbolismo nas paisagens humanas. In: CORREAA, R, L. \& ROZENDAHL, Z. (orgs.). Paisagem, Tempo e Cultura. Rio de Janeiro: EdUERJ, 1998.

FERREIRA, M. de M. e AMADO, J. (orgs.). Usos \& abusos da história oral. Rio de Janeiro: Fundação Getúlio Vargas, 1996.

FRÉMONT, A. A região, espaço vivido. Almedina, Coimbra, 1974.

HAESBAERT, R. O Mito da Desterritorialização: do "fim dos territórios" à multiterritorialidade. Rio de Janeiro: Bertrand Brasil, 2004.

HAESBAERT, R. Epílogo: Hibridismo, mobilidade, e Multiterritorialidade Abordagem Cultural da Geografia: numa perspectiva Geográfico-Cultural Integradora .In: SERPA, Ângelo. (Org.) Espaços Culturais, Vivências, Imaginação e Representações. Salvador: UFBA, 2008.

HALBWACHS, M. A memória coletiva. São Paulo: Editora Vértice, 1990.

JORNAL A UNIÃO. Comunidade do Talhado resiste e mantém tradições. http://www.auniao.pb.gov.br/v2/ index.php?option=com_content\&task=view\&id=14156\&Itemid=44 Acesso em agosto de 2010.

LE GOFF, J. Documento Monumento. In: História e Memória. São Paulo: UNICAMP, 1994

LEAL, G. F. O poder dos donos da Terra: um balanço das organizações de proprietários e empresários rurais na década de 90. Raízes, Campina Grande, vol. 22, nº. 2, p. 202-211, jul/dez. 2003.

LEITE, M. M. Retratos de Família: leitura da fotografia histórica. São Paulo: Editora da Universidade de São Paulo, 1993.

MACENA, H. L. dos S.. De Quilombo a Quilombola: "um" olhar sobre a comunidade remanescente de quilombo de Pitombeira, Várzea - PB. João Pessoa: 2008.

MARTINS, J. de S. Os camponeses e a política no Brasil. In: Os camponeses e a política no Brasil. Rio de Janeiro: Vozes, 1981.

MARTINS, J. de S. Os Camponeses e a Política no Brasil. Rio de Janeiro: Vozes, 1986

MOREIRA, A. P.da C; RODRIGUES, M. de F. F. Politicas Públicas em Territórios Quilombolas: o caso de Caiana dos Crioulos. In: I SEMINÁRIO LUSO - BRASILEIRO-CABOVERDIANO, 1, 2006. João Pessoa. Anais do SEMILUSO. João Pessoa: UFPB, 2006.

MORIN, E. A cabeça bem-feita: repensar a reforma, reformar o pensamento. Rio de Janeiro: Bertrand Brasil, 2006.

MOURA, M. M.. Camponeses. São Paulo: Ática, 1986.

NÓBREGA, J. E. da. Comunidade Talhado um grupo étnico de remanescente quilombola: uma identidade construída de fora? (Dissertação de Mestrado). Campina Grande: UEPB/MICS, 2007.

OLIVEIRA, A. U de. A agricultura camponesa no Brasil. São Paulo, Contexto, 1991.

OLIVEIRA, P. de S. Memória e Sociedade: ciência poética e referência de humanismo. Psicol, São Paulo, v.19 n.1, março 2008.

PAIVA, R. de.; SOUZA, V. R. F. de P.. Caiana dos Crioulos, Alagoa Grande-PB. Relatório de Identificação. In: Projeto Mapeamento e Identificação das Áreas Remanescentes de quilombos. Recife, junho de 1998. QUEIROZ, M. I. P. de. Experimentos com histórias de vida. São Paulo: Vértice, 1988.

RAFFESTIN, C. Por uma Geografia do poder. São Paulo: Ed. Ática, 1993.

RATTS, A. J. P. A Geografia entre as aldeias e os quilombos - Territórios etnicamente diferenciados In: ALMEIDA, M. G. de; RATTS, A. J.P. (Orgs). Geografia: Leituras Culturais. Goiânia: Ed. Alternativa, 2003. 
RODRIGUES, M. de F. F. Terra Coletiva, Terra Comunitária: realidade ou mistificação. In: Revista Geousp, São Paulo-USP: Humanitas FFLCH/USP, março, 1998.

SANTOS, B. de S. Renovar a teoria crítica e reinventar a emancipação social. São Paulo: Boitempo, 2007. TUAN, Y.F. Topofilia: um estudo da percepção, atitudes e valores do meio ambiente. São Paulo: Difel, 1980. WOLF, E. R. Sociedades Camponesas. Curso de Antropologia Moderna. Rio de Janeiro: Zahar Editores, 1970.

WOORTMANN, K. Com Parente Não se Neguceia: o Campesinato como ordem moral. Anuário Antropológico, n. 87, Editora UnB, Brasília: Tempo Brasileiro, 1990.

BOBBIO, N. Os intelectuais e o poder: dúvidas e opções dos homens de cultura na sociedade contemporânea. São Paulo: Editora da UNESP, 1997.

Trabalho enviado em janeiro de 2011 Trabalho aceito em abril de 2011 